\title{
THE INFLUENCE CELLULAR PROVIDER SERVICE QUALITY TOWARDS CUSTOMER LOYALTY INDOSAT IN JAKARTA
}

\author{
Dita Puruwita \\ Fakultas Ekonomi Universitas Negeri Jakarta \\ Email : dita.puruwita@gmail.com
}

\begin{abstract}
This research aims are to find out how well the service quality of PT Indosat Jakarta, how loyal are the customers, and how far the effect of the service quality toward the customers loyalty Indosat in Jakarta. The category of this research are descriptive and verification with surveys method by using a convenience sampling. The sample sizes is 120 respondents of Indosat customers. Therefore, the data collecting technique used are from secondary data, interview, observation and questionnaires. The result of this research based on hypothetical test indicates that there is a effect between the service quality and the customer loyalty. The conclusion of this research is that the performance of the service quality provided by Indosat is still under the customer expectation. It is suggested to the management of PT. Indosat, to improve and maintain their service quality in the dimension that is regard as important, as well the customer's loyalty level.
\end{abstract}

Keywords : Service Quality, Customer Loyalty, Indosat

\section{PENDAHULUAN}

Industri telepon seluler
mengalami perkembangan yang pesat baik di negara maju ataupun sedang berkembang. Belum lagi ditambah perilaku konsumen yang saat ini semakin tergantung dengan ponsel sebagai alat berkomunikasi.Dengan meningkatnya permintaan jasa layanan komunikasi, akan membuka peluang pasar baru baik bagi operator jasa komunikasi. Perkembangan yang pesat pada industri telekomunikasi ini juga didorong oleh pekembangan yang pesat dari pasar seluler.Fenomena yang terjadi di industri seluler adalah adanya persaingan yang semakin ketat antar operator dalam 
menarik konsumen supaya tertarik untuk menggunakan produknya, khususnya untuk fixedline wireless ataupun seluler.Bahkan dalam beberapa media kita saksikan perang harga untuk menarikpelanggan dilakukan oleh berbagai operator. Sehingga masyarakat ataupunkonsumen yang mulai cerdas banyak memanfaatkan perang harga tersebut untukmendapatkan harga termurah Salah satu operator seluler yang ada di Indonesia yaitu Indosat, yang akan dijadikan unit observasi dalam penelitian ini. Indosat tidak dapat melepaskan diri dari persaingan antar operator lainnya, hal ini dilihat dari tingginya angka churn rate yang juga terjadi pada operator seluler Indosat. Di Indosat sendiri pada saat ini tingkat kartu hangus (Churn) Indosat mencapai 10-11 persen (Irianto, 2009). Dalam dunia telekomunikasi, perusahaan perusahaan penyedia layanan jasa telekomunikasi di dunia akan kehilangan minimal 2 - $4 \%$ customernya setiap bulannya, dan hal ini akan menimbulkan kerugian dari profit yang diinginkan oleh perusahaan. Peningkatan customer loyalty pelanggan dalam bidang industri jasa sebesar 5\% akan mendatangkan keuntungan 25 75\% (Aydin, 2005:910), sebuah profit yang sangat besar dengan dengan sering berganti operator ataupun memilikibeberapa jasa pelayanan dari beberapa operator.

Pelanggan telepon seluler di Indonesiabegitu mudah untuk berganti nomor telepon ke operator lain. Hal ini diperkirakan dipicu oleh ragam promosi dari operator terutama dalam hal tarif yang cenderung berlebihan namun mengabaikan kualitas layanan.

meningkatnya customer loyalty 5\% saja. Oleh karena itu churn dapat dikatakan adalah ancaman. Perolehan ribuan pelanggan akan sia-sia jika jumlah yang sama berpaling ke operator lain, sementara upaya memperoleh pelanggan yang baru sendiri perlu biaya lebih mahal. Sehingga merupakan hal yang tidak mudah bagi pihak Indosat untuk dapat mempertahankan pelanggannya supaya tetap menggunakan jasa telepon selulernya.

Dari berbagai aktivitas yang dilakukan Indosat dalam melakukan layanan jasa, Selain menghadapi masalah churn, Indosat juga dihadapkan pada masalah menyangkut kesenjangan (gap) dalam kualitas jasa yang disampaikan dengan yang diharapkan pelanggan yang pada akhirnya akan mempengaruhi loyalitas pelanggan.Kesenjangan ini 
dilihat dari adanya keluhan pelanggan melalui media cetak maupun elektronik mengenai kualitas jasa Indosat. Keluhan masyarakat mengenai kualitas jasa operator seluler antara lain yaitu pelayanan petugas operator yang lamban dan seringkali tidak bersahabat, pada saat pelanggan menanyakan atau meminta informasi dan juga operator seluler yang tidak melaksanakan janji pelayanan.

Dimensi pengukuran kualitas jasa yang dilakukan adalah tangibles, reliability, responsiveness, empathy, dan assurance (Zeithaml (dalam Wall, et all 2002:325)). Lima dimensi inilah yang menjadi indikator untuk menciptakan pelayanan yang prima. Tujuan dari penelitian ini adalah untuk mengetahui bagaimana kualitas jasa yang dirasakan oleh pelanggan Indosat, bagaimana loyalitas pelanggan Indosat dan bagaimana pengaruh kualitas jasa provider seluler terhadap loyalitas pelanggan Indosat.

\section{KAJIAN TEORETIK}

Kualitas Jasa

Kualitas jasa menurut Gronroos (dikutip oleh Wong 2003:496) adalah :"as a perceived judgement, resulting from an evaluation process where customers compare their expectations with the service they perceive to have received". Zeithaml ( 2009 : 117 ) mengkategorikan dimensi kualitas jasa secara umum sebagai berikut :

1. Tangibles, termasuk fasilitas fisik dari penyedia jasa atau perusahaan, perlengkapan, penampilan petugas, dekorasi ruangan dan peralatan komunikasi.

2. Reliability, mengacu kepada kemampuan dari penyedia jasa untuk memberikan pelayanan dengan teliti dan dapat dipercaya, sesuai dengan yang dijanjikan.

3. Responsiveness, mengacu kepada kesediaan dari pegawai perusahaan untuk membantu pelanggan dan untuk menyediakan jasa yang diinginkan pelanggan dengan cepat.

4. Assurance, mengacu kepada pengetahuan dan kesopanan dari pegawai perusahaan dan kemampuan mereka untuk menumbuhkan rasa percaya dan keyakinan pada pelanggan terhadap perusahaan.

5. Empathy, mengacu kepada kemampuan penyedia jasa untuk memberikan rasa peduli dan perhatian kepada setiap pelanggan. Dimana suatu perusahaan diharapkan memiliki pengertian dan pengetahuan tentang pelanggan, 
memahami kebutuhan pelanggan secara spesifik.

Kualitas jasa dipengaruhi oleh dua variabel, yaitu jasa yang dirasakan (perceived service) dan jasa yang diharapkan (expected service). Bila jasa yang dirasakan lebih kecil daripada yang diharapkan, para pelanggan menjadi tidak tertarik pada penyedia jasa yang bersangkutan. Sedangkan bila yang terjadi adalah sebaliknya (perceived > expected), ada kemungkinan para pelanggan akan menggunakan penyedia jasa itu lagi.

\section{Loyalitas Pelanggan}

Mowen dan Minor (2002:108)

mendefinisikan loyalitas sebagai kondisi di mana pelanggan mempunyai sikap positif terhadap suatu merek, mempunyai komitmen pada merek tersebut, dan bermaksud meneruskan pembeliannya di masa mendatang.

Loyalitas juga merupakan perilaku non random sebagai reaksi dari hasil proses evaluasi yang mendorong ke arah komitmen. Konsep loyalitas lebih banyak dikaitkan dengan perilaku daripada dengan sikap. Griffin (dikutip oleh Wong 2003:497), memberikan pengertian loyalitas "Customer loyalty is apurchase behaviour, unlike customer satisfaction, which is an attitude"
Seseorang yang merupakan pelanggan loyal, ia akan menunjukkan perilaku pembelian yang didefinisikan sebagai pembelian nonrandom yang diungkapkan dari waktu ke waktu oleh beberapa unit pengambilan keputusan. Seorang pelanggan yang loyal memiliki prasangka spesifik mengenai apa yang akan dibeli dan dari siapa. Pembelinya bukan merupakan peristiwa acak. Selain itu loyalitas menunjukkan kondisi dari durasi waktu tertentu dan mensaratkan bahwa tindakan pembelian terjadi tidak kurang dari dua kali. Unit pengambilan keputusan menunjukkan bahwa keputusan untuk membeli mungkin dilakukan oleh lebih dari satu orang. Menurut Griffin ( 2005:31), pelanggan yang loyal adalah orang yang : (1). Melakukan pembelian ulang secara teratur. (2). Melakukan pembelian antarlini produk dan jasa. 3. Memberikan referensi kepada orang lain, (4). Menunjukkan kekebalan terhadap tarikan dari pesaing.

\section{Kerangka Berpikir}

Dalam era persaingan yang ketat, kualitas pelayanan merupakan komponen yang penting bagi perusahaan. Hal ini dikarenakan perusahaan yang mampu bertahan dan unggul dibandingkan pesaingnya adalah 
perusahaan yang mampu memberikan pelayanan yang berkualitas. Bisnis telekomunikasi merupakan satu jenis usaha bidang layanan jasa sedang meningkat pesat saat ini. Sistem pelayanan merupakan produk yang sangat penting bagi perusahaan yang bergerak di bidang jasa, karena berhubungan langsung dengan upaya memperoleh pelanggan baru dan upaya mempertahankan pelanggan lama. Kualitas jasa yang diberikan penyedia jasa kepada para pelanggannya akan berdampak pada loyalitas. Penyedia jasa yang tidak memperhatikan kualitas jasa akan menanggung resiko pelanggan menjadi tidak loyal. Kualitas jasa yang baik memberikan manfaat diantaranya memberikan dasar yang kuat bagi pembelian ulang dan terciptanya loyalitas (chun lee, et all 2003:423). Tjiptono (2006:55) juga mengungkapkan bahwa kualitas yang superior memberi manfaat antara lain berupa loyalitas pelanggan.

Secara konseptual terdapat pola hubungan antara kualitas jasa terhadap loyalitas pelanggan, dimana kualitas jasa telepon seluler dapat dijadikan prediktor bagi loyalitas pelanggan .

\section{Hipotesis}

Berdasarkan kerangka pemikiran diatas maka dapat dirumuskan hipotesis sebagai berikut :

1. Kinerja kualitas jasa Indosat Baik.

2. Loyalitas pelanggan Indosat terhadap kartu seluler Indosat tinggi.

3. Kualitas jasaberpengaruh terhadap loyalitas pelanggan Indosat.

\section{METODOLOGI PENELITIAN}

Jenis penelitian ini adalahdeskriptif-verifikatif, Metode penelitian yang digunakan adalah metode penelitian survei. Pengambilan sampel yang digunakan adalah teknik convenience sampling. Prosedur pengumpulan data yang akan digunakan dalam penelitian ini adalah merupakan kombinasi dari pengumpulan data dengan menggunakan data sekunder, observasi, kuesioner, wawancara.

\section{HASIL PENELITIAN DAN PEMBAHASAN}

\section{Pengujian Hipotesis Pertama}

Pengujian ini dilakukan untuk melihat ada atau tidaknya perbedaan antara rata-rata kualitas jasa yang dirasakan pelanggan dengan yang diharapkan pelanggan. 
Ho : $\mu 1=\mu 2$ Rata-rata kualitas jasa pada yang dirasakan pelanggan sama dengan yang diharapkan pelanggan
$\mathrm{H}_{1}: \mu 1 \neq \mu 2$ Rata-rata kualitas jasa yang dirasakan pelanggan tidak sama dengan yang diharapkan pelanggan

\section{Tabel 1}

Uji Beda Rata-Rata

\begin{tabular}{|c|c|c|c|c|c|}
\hline Variabel & Rata-Rata & t hitung & df & $\mathbf{t}$ tabel & $\begin{array}{c}\text { p-value } \\
\text { (sig) }\end{array}$ \\
\hline $\begin{array}{c}\text { Kualitas Jasa } \\
\text { (Yang Dirasakan Pelanggan) }\end{array}$ & 63.7417 & $\mathbf{- 1 0 , 6 1 3}$ & 119 & \pm 1.98 & 0.000 \\
\hline $\begin{array}{c}\text { Kualitas Jasa } \\
\text { (Yang Diharapkan Pelanggan) }\end{array}$ & 80.8917 & & & \\
\hline
\end{tabular}

Berdasarkan hasil perhitungan diperoleh $\mathrm{t}$ hitung sebesar - 10,613 dengan signifikansi sebesar 0,000 . Karena nilai t hitung $(-10,613)<$ nilai $-t$ tabel $(-1,98)$, maka Ho ditolak. Hal ini menunjukkan bahwa terdapat perbedaan Kualitas Jasa yang dirasakan pelanggan dengan yang diharapkan pelanggan. Dari hasil perhitungan diperoleh rata-rata Kualitas Jasa yang dirasakan pelanggan adalah sebesar 63,7417. Sedangkan rata-rata Kualitas Jasa yang diharapkan pelanggan adalah sebesar 80,8917. Hal ini mengindikasikan bahwa rata-rata Kualitas Jasa yang dirasakan pelanggan kurang dari kualitas jasa yang diharapkan pelanggan, berarti bahwa kualitas jasa provider seluler belum dapat memenuhi yang diharapkan pelanggan.

\section{Pengujian Hipotesis Kedua Loyalitas Pelanggan Indosat}

Pengujian ini dilakukan untuk melihat bagaimana loyalitas pelanggan Indosat di Jakarta.

Ho: $\mu \leq \mu_{0}$ Pelanggan tidak loyal terhadap kartu seluler Indosat

$\mathrm{H}_{1}: \mu>\mu_{0} \quad$ Pelanggan loyal terhadap kartu seluler Indosat Kriteria Uji : Terima Ho jika t hitung $<\mathrm{t}$ table atau Tolak Ho jika t hitung $>t$ table 
Tabel 2

Uji Beda Rata-Rata

\begin{tabular}{|c|c|c|c|c|c|}
\hline Variabel & Rata-Rata & t hitung & df & t table & $\begin{array}{c}\text { p-value } \\
\text { (sig) }\end{array}$ \\
\hline Loyalitas Pelanggan & 0.7208 & 20.105 & 119 & \pm 1.98 & 0.000 \\
\hline
\end{tabular}

Berdasarkan

hasil

perhitungan diperoleh rata-rata loyalitas pelanggan adalah sebesar 0,7208 dan nilai $t$ hitung sebesar 20,105 dengan signifikansi sebesar 0,000 . Karena nilai t hitung $(20,105)$ $>$ nilai $\mathrm{t}$ tabel $(1,98)$, maka $\mathrm{Ho}$ ditolak. Hal ini menunjukkan bahwa rata-rata loyalitas pelanggan sudah lebih dari $50 \%$ sehingga dapat dikatakan bahwa pelanggan Indosat sudah loyal terhadap kartu seluler Indosat .

\section{Pengujian Hipotesis Ketiga \\ Pengaruh Kulitas jasa terhadap Loyalitas Pelanggan Indosat.}

Pengujian hipotesis dilakukan untuk mengetahui besar pengaruh Kualitas jasaterhadap Loyalitas Pelanggan (Y). Diperoleh pengaruh kualitas jasaterhadap loyalitas pelanggan kartu seluler Indosat adalah sebesar $47,3 \%$ sedangkan besarnya faktor lain adalah $52,7 \%$. $\mathrm{R}$ square atau koefisien determinasi menunjukkan seberapa besar variabel $X$ dapat menggambarkan variabel $Y$. Dengan nilai $R$ square $47,3 \%$ berarti bahwa variabel kualitas jasa dapat menggambarkan variabel loyalitas pelanggan sebesar $47,3 \%$. Sisanya adalah 52,7\% dijelaskan oleh variabel-variabel yang tidak diteliti dalam penelitian ini.

\section{KESIMPULAN DAN SARAN KESIMPULAN}

Berdasarkan hasil penelitian dan pembahasan maka dapat disimpulkan beberapa hal pokok sebagai berikut :

1. Kualitas jasa yang diberikan oleh PT. Indosat kinerjanya belum dirasakan sepenuhnya oleh pelanggan. Skor kesenjangan terkecil ada pada indikator tampilan tayangan iklan Indosat. Skor kesenjangan terbesar terdapat pada indikator kemudahan dalam menghubungi customer service. Kinerja Indosat yang dirasakan pelanggan kurang adalah adalah kecepatan pegawai dalam memberikan pelayanan, kesediaan petugas Indosat merespon permintaan pelanggan, kualitas sinyal yang diterima pelanggan tidak stabil. Indosat juga dinilai belum mampu memberikan rasa percaya kepada pelanggan terutama dalam 
hal penetapan tarif dan kemudahan pelanggan dalam menghubungi customer service Indosat.

2. Tingkat loyalitas pelanggan Indosat berada dalam kategori loyal. Tingkatan loyalitas pelanggan terdiri dari customers 120 pelanggan, repeat customers sebanyak 100 pelanggan, client sebanyak 69 pelanggan sedangkan advocates sebanyak 25 pelanggan.

3. Terdapat pengaruh antara kualitas jasa terhadap loyalitas pelanggan Indosat sebesar $47,3 \%$.

\section{SARAN}

Setelah mengamati dan dirangkum dalam kesimpulan maka saran yang dapat diajukan adalah sebagai berikut:

1.Indosat

mengkonsentrasikan

sebaiknya

kinerjanya pada indicator yang masuk pada kategori kuadran A, yaitu dengan cara Indosat melalui lembaga risetnya dipandang perlu melakukan kajian terhadap jaringannya dalam upaya untuk mencapai akses sinyal yang optimal bagi pelanggan dengan cara menambah kapasitas, kualitas dan jangkauan layanan. Indosat juga dipandang perlu untuk melakukan evaluasi dalam pelaksanaan standar pelayanan yang sudah dilaksanakan oleh Indosat saat ini melalui bagian pelayanannya.
Indosat juga dipandang perlu melakukan evaluasi terhadap pelatihan secara berkala yang sudah ada disesuaikan dengan kebutuhan pelanggan yang semakin banyak. Indosat juga dipandang perlu mengevaluasi kemampuannya untuk memenuhi janji-janji yang tertuang dalam iklan dan menghindari sikap over promise sehingga kepercayaan pelanggan terhadap Indosat dapat terjaga. Selain itu Indosat juga dipandang perlu untuk mempertimbangkan penambahan customer service dan line telepon/call center, disesuaikan dengan cost yang ada sehingga pelanggan tidak lagi mengalami kesulitan dalam menghubungi call center Indosat.

2. Untuk mempertahankan loyalitas pelanggan dapat dilakukan dengan terus konsisten menjaga kualitas pelayanan yang diberikan sehingga mencapai tingkat kepuasan yang diharapkan pelanggan yang pada akhirnya dapat meningkatkan loyalitas pelanggan dan berupaya untuk terus membangun hubungan yang lebih baik kepada pelanggan Indosat melalui program-program yang memiliki nilai tambah, seperti mengadakan acara-acara musik yang dapat mendekatkan Indosat kepada pelanggannya.

3.Kualitas jasa bukan satu-satunya variabel yang mempengaruhi 
loyalitas pelanggan. Indosat diharapkan senantiasa melakukan upaya-upaya lain yang dapat meningkatkan loyalitas pelanggannnya.

\section{DAFTAR PUSTAKA}

Azwar Saifuddin. 2008. Reliabilitas dan Validitas, Penerbit Pustaka Pelajar, Yogyakarta. p 158

Aydin, Serkan \& Gokhan Ozer. 2005. The Analysis of Antecedents of Customer Loyalty in the Turkish Mobile Telecommunication Market. European Journal of Marketing Vol. 39 No. 7/8. P.911-912,921

Chun, San Lee ; Sunita Barker and Jay Kandampully . 2003. Technology, Service Quality, and Customer Loyalty in Hotels:Australian Managerial Perspektives. Managing Service Quality.Vol 13, No 5.P 423

Cooper, Donald \& Pamela S. Schindler. 2006. Marketing Research. New York : McGraw Hill. P.417, 446

Fandy Tjiptono, 2007. Pemasaran Jasa . Malang: Bayumedia Publishing. P,390 2006. Manajemen Jasa edisi 4. Yogyakarta : Andi Offset. P 55, 60,61
Fandy Tjiptono \& Gregorius Chandra. 2005. Service, Quality \& Satisfaction. Yogyakarta : Andi. P.115, 119 Griffin, Jill. 2005. Customer Loyalty : Menumbuhkan dan Mempertahankan Kesetiaan Pelanggan. Terjemahan Dwi Kartini Yahya. Jakarta : Erlangga. $P$. $11,22,31,35,51,101,140$

Ismail, Ismail; Hasnah Haron; Daing Nasir Ibrahim and Salmi Mohd Isa. 2006.Service Quality, Client Satisfaction and Loyalty Towards Audit Firms:Perceptions of Malaysian public listed companies. Managerial Auditing Journal. Vol. 21 No. 7.P 742,744

Kotler, Philip \& Kevin Lane Keller. 2009. Marketing Management $12^{\text {ed }}$. New Jersey : Pearson International Edition. P. 386, 375-377

Nirwana Sitepu. 1994. Analisis Jalur. Bandung : Unit Pelayanan Statistik Jurusan FMIPA UNPAD. P.108

Sivadas, Eugene \& Jamie L. BakerPrewitt. 2000. An Examination of the Relationship Between Service Quality, Customer Satisfaction, and Store Loyalty. International Journal of Retail \& Distribution Management. Vol 28 No 2. P73 
Sugiono. 2007. Statistika Untuk Penelitian. Bandung : CV Alfabeta. P.61, 359

Wal, Van Der R.W.E ; A. Pampallis ; and C.Bond. 2002. Service Quality in a Cellular Telecommunications Company : A South African Experience, Managing Service Quality. Vol 12, No 5. P 325
Wong, Amy \& Amrik Sohal. 2003. Service Quality and Customer Loyalty Perspectives on Two Levels of Retail Relationships. Journal of Service Marketing. Vol 17 No 5. P 495-497.P505

Zeithaml, Valerie A \& Mary J. Bitner. 2009. Service Marketing. United States :McGraw-Hill inc. P. $4,46,117$ 